\title{
The Effect of Parenting Style in Junior High School Adolescent's Self-Esteem
}

\author{
I. Gusti Ayu Trisna Windiani ${ }^{1}$, Sri Maya ${ }^{2,}$, , . Gusti Ngurah Sanjaya Putra ${ }^{1}$, Ida Bagus Subanada ${ }^{1}$ \\ ${ }^{1}$ Department of Child Health, Faculty of medicine, Udayana University, Denpasar, Indonesia \\ ${ }^{2}$ Department of Child Health, Sondosia General Hospital, Bima, West Nusa Tenggara, Indonesia
}

\section{Email address:}

trisnawindianidr@yahoo.co.id (I. G. A. T. Windiani), srimaya99@yahoo.com (S. Maya), sanjayaputra65@gmail.com (I. G. N. S. Putra), subanada@yahoo.com (I. B. Subanada)

${ }^{*}$ Corresponding author

\section{To cite this article:}

I. Gusti Ayu Trisna Windiani, Sri Maya, I. Gusti Ngurah Sanjaya Putra, Ida Bagus Subanada. The Effect of Parenting Style in Junior High School Adolescent's Self-Esteem. American Journal of Pediatrics. Vol. 5, No. 4, 2019, pp. 224-229. doi: 10.11648/j.ajp.20190504.20

Received: September 29, 2019; Accepted: October 14, 2019; Published: October 23, 2019

\begin{abstract}
Self-esteem is important in adolescent, with good self-esteem adolescents able to actualize their potential to create positive social interactions. Self-esteem increases in children, decreases in adolescence and increases in adulthood then declines in old age. The level of self-esteem is influenced by significant people, especially parents. The objective was to prove adolescents from non-democratic parenting style have lower self-esteem than democratic parenting style. The study was conducted in Government Junior High School Denpasar from January until April 2018. Schools were chosen by simple random sampling, meanwhile samples were collected consecutively. Parenting styles was assessed by Kuesioner Pola Asuh Anak (KPAA) and self-esteem by Rosenberg questionnaire. Statistic analysis was performed by Chi-square test followed by multivariate logistic regression analysis, significancy level was set to $\mathrm{p}<0.05$, confident interval (CI) $95 \%$. Total 125 adolescents enrolled in this study, 21 were excluded, 104 samples including 52 adolescents from democratic parenting style and 52 adolescents from non-democratic parenting style. Clinical different was found in mother's occupation meanwhile bivariate analysis with Chi-square showed significant different of low self-esteem $32.7 \%$ in non-democratic, $5.8 \%$ in democratic parenting style ( $\mathrm{p}=0.001 ; \mathrm{RP}=5.667, \mathrm{CI}$ : 1.766 to 18.178 ). Finally multivariate logistic regression analysis showed low self-esteem in adolescent was influenced by non-democratic parenting style. This study concluded non-democratic parenting style is risky to induce low self-esteem in adolescent.
\end{abstract}

Keywords: Adolescent, Self-esteem, Parenting Style, Democratic, Non-democratic

\section{Introduction}

Self-esteem, the ability of individual to assess ownself [1] and belief in self-ability to overcome life's challenges, ability to think, feeling success, happy and worthy [2]. Self-esteem is fundamental human needs in developmental stages from adolescence to adulthood because with high self-esteem adolescent able to actualize their potential to create positive social interaction [3]. Self-esteem increases in childhood, decreases in adolescence, increases again in adulthood then declines in the seventies [2].

Level of self-esteem is influenced by treatment received from significant person especially parents and their respond to failure or success in achievement [5]. Other factors that also contribute to self-esteem are parenting styles [6], socioeconomic status [7], parents' education level [8], gender [9], genetic [10], social media [11], psychiatric disorders and chronic diseases $[12,13]$.

Adolescents with high self-esteem see themselves valuable, optimist, eager to try new things, confident and away from aggressivness while low self-esteem adolescents have poor perception of themselves, consider themselves as failure, worthless, clumsy and susceptible to frustration [126].

Parenting is parent and child interaction process over a wide range of situations and creates an effective interaction atmosphere [17]. There are 4 types of parenting styles: authoritarian, democratic, permissive and neglectful 
parenting style. In authoritarian parenting style, parents tend to be harsh and rigid in applying rules. In democratic parenting style parents tend to be responsive, child-centered with control without punishment meanwhile in permissive parenting style parents tend to give unlimited freedom to child, without punishment and achievement goals from child, addition parents also try to avoid conflict. Neglectful parenting style is inconsistent parenting pattern, parents don't supervise their child and the relationship between parent and child isn't intimate [18-20]. The objective of this study was to prove adolescents from non-democratic parenting style have lower self-esteem than democratic parenting style.

\section{Materials and Methods}

This is cross-sectional study to determine adolescent's self-esteem from democratic and non-democratic parenting styles. Samples were collected by simple random sampling, with approval from Research and Development Unit, Udayana Medical Faculty (No. 2017.02.1.0997) and Department of Youth and Sports Education (No: 440/20217/DIKPORA/2017).

Inclusion criteria in these study consist of: (1) adolescent whom study in grade 7 of government high school which known as SMPN (Sekolah Menengah Pertama Negeri); (2) adolescent from democratic and non-democratic parenting style; (3) agree to participate in this study stated by parents sign informed consent; (4) adolescent whom lives with both parents. Exclusion criteria consist of: (1) adolescent who doesn't fill completely or submit the questionnaire form; (2) adolescent with chronic illness; (3) adolescent with mental illness.

Purpose and procedure of study were explained to adolescent and their parents. Adolescents whom agree to participated, submit the informed consent that had been signed by their parents and filled the forms (age, gender, family income, parents' occupation and social media, Rosenberg and KPAA form).

\subsection{Variables Definition}

Self-esteem is individual attitude in understanding own self, includes satisfaction with own self to accept and respect which consists of self-acceptance and self-respect, measured by the Rosenberg scale. Score $<15$ : low self-esteem, score 15-30: high self-esteem.

Parenting style is father and mother attitude in raising and educating their child, asses with Child Care Case Questionnaire (KPAA). The democratic parenting style is parenting style of father and mother with balance control and warmth, with highest score in point A based on the KPAA. The non-democratic parenting style is parenting pattern of father and mother with unbalanced control and warmth including authoritarian, permissive or neglectful parenting style.

Authoritarian parenting style is parenting pattern of demanding and dominant parents, characterized by the highest score point $\mathrm{B}$ based on KPAA.

Permissive parenting style is characterized by full freedom from parents, marked with the highest score point $\mathrm{C}$ based on KPAA. Neglectful parenting style is inconsistent parenting pattern with equal values the 2-3 point based on KPAA.

Age was determined based on chronological age (date of birth), expressed in years by rounding down if below 6 months and rounding up if above 6 months, obtained from interview. The parents' education level was devided into not attending school, graduate from: elementary school, junior high school, high school, university. Occupation was divided into entrepreneurs, goverment officer, private employees and unemployed. Family income was assessed based on Denpasar UMR 2017 of 2,173,000, divided into 3 categories: below $2,173,000,2,173,000$ to $5,000,000$ and above 5,000,000. Active users of social media was defined as individu who use social media (either just look, add status, add photos) with minimum duration more than 3 hours daily, 3 times weekly.

\subsection{Scoring Technique}

Rosenberg scale: the answer in this scale ranges from 0 to 3 , example: strongly disagree $=0$, disagree $=1$, agree $=2$ and strongly agree $=3$ in favorable items $(1,2,4,6$ and 7), scoring was done by giving values according to the participant's answer scale. In contrast to unfavorable items $(3,5,8,9$, and 10) scoring done reversely with favorable items, for example for strongly disagree $=3$, disagree $=2$, agree $=1$ and strongly agree $=0$. Score $<15$ indicates low self-esteem.

Table 1. Favorable and unfavorable items.

\begin{tabular}{lll}
\hline Item & Item number & Sample item \\
\hline Positive (favorable) & $1,2,4,6$ and 7 & I feel that I have a number of good qualities. \\
Negative (unfavorable) & $3,5,8,9$, and 10 & Overall, I tend to feel that I am a failure \\
\hline
\end{tabular}

Parenting Questionnaire (KPAA): raw score is calculated by summing values obtained from 54 questions in group $\mathrm{A}(\mathrm{A}=1$; $\mathrm{B}=2$; $\mathrm{C}=3$ ). There are 2 separate assessments of the father's assessment and the mother's assessment, each with a total of 27 questions and highest score 81 each parent. Then assessed the difference between "A B C" and the reference value of item $\mathrm{A}=1 ; \mathrm{B}=2 ; \mathrm{C}=3$. The highest score shows the characteristics of the parenting style:

1. Character A: democratic parenting, marked by the highest value in point $\mathrm{A}$ which shows a considerate parent.

2. Character B: authoritarian parenting style, marked by the highest value in point $B$ showing the most demanding and dominant parenting pattern.

3. Character $C$ : permissive parenting style, marked by the highest value in point $\mathrm{C}$ which shows parenting style with full freedom, minimal parental intervention.

4. Character D: neglectful parenting style, inconsistent 
parenting is characterized by 2-3 equal values from the same $\mathrm{A}, \mathrm{B}$ and $\mathrm{C}$ points.

\section{Results}

One hundred twenty five adolescents met the inclusion criteria, with following details: (1) 28 adolescents in SMPN I, we obtained 11 teenagers of democratic parenting and 11 adolescents of non-democratic parenting, 6 adolescents were excluded because incomplete questionnaire; (2) 24 adolescents in SMPN III, we obtained 11 adolescents of democratic parenting and 11 adolescents of non-democratic parenting, 2 adolescents were excluded because they didn't submit the questionnaires; (3) 28 adolescents in SMPN IV, we obtained 10 adolescents of democratic parenting and 10 adolescents of non-democratic parenting, 8 adolescents were excluded because incomplete questionnaire; (4) 22 adolescents SMPN VI we obtained 10 adolescents of democratic parenting and 10 adolescents of non-democratic parenting, 2 adolescents were excluded because incomplete questionnaire; and (5) 23 adolescents in SMPN VII we obtained 10 democratic parenting adolescents and 10 nondemocratic parenting adolescents, 3 adolescents were excluded because they didn't submit questionnaires (Figure 1).

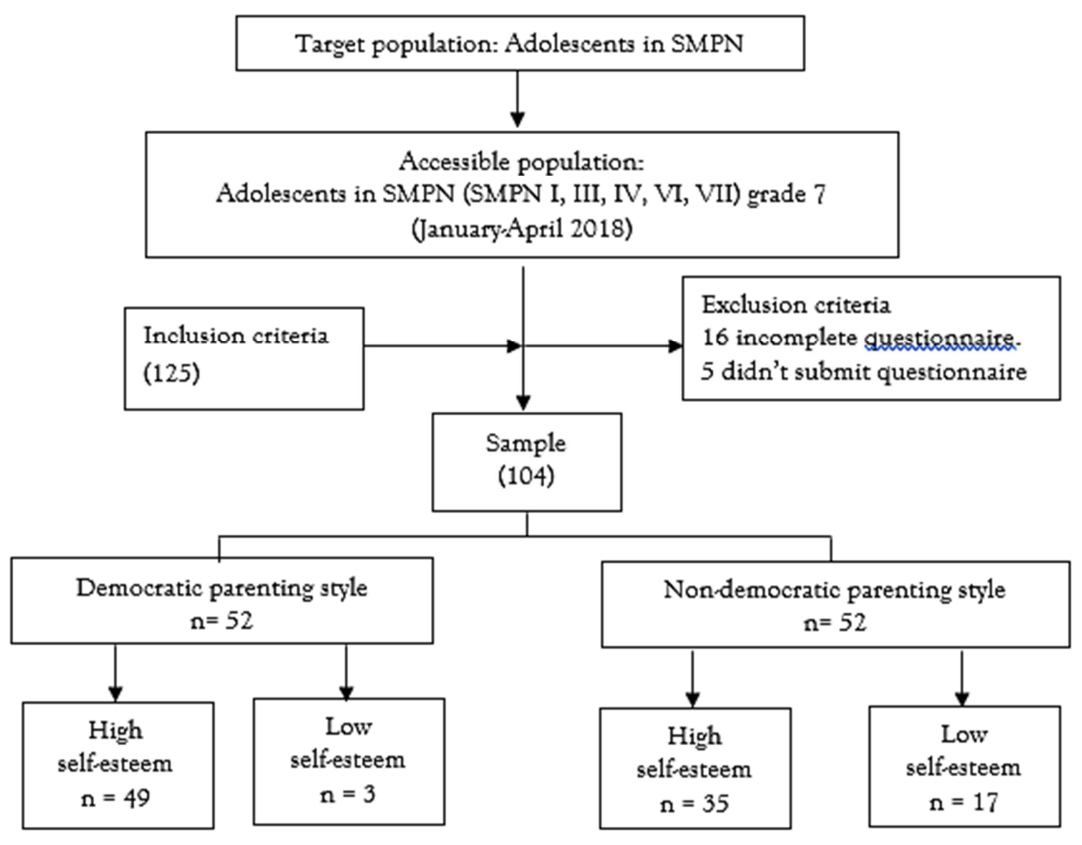

Figure 1. Scheme study.

The study was dominated by 12-year-olds adolescents and social media users in both parenting styles with the domination of female adolescent in non-democratic parenting style; while in sector of family income, both parenting styles are dominated by income 2,173,000 - 5,000,000 and college graduates.

The father's occupation in democratic parenting style was dominated by entrepreneur, differ from non-democratic father which was dominated by private employees. The majority occupation of mothers with democratic parenting style were private employees, while non-democratic mothers were unemployed. The characteristics of those both parenting styles didn't appear differ clinically, except in terms of the mother's occupation.

Bivariate analysis showed different proportion of low selfesteem adolescents between non-democratic (32.7\%) and democratic parenting style $(5.8 \%)$ [prevalent ratio $(\mathrm{PR})=$ $5.667 ; \mathrm{CI}=1.766$ to 18.1781$]$, which implicate nondemocratic parenting style is risk factor for low self-esteem in adolescents (Table 2), then multivariate test was done to analyze mother's occupation and non-democratic parenting style which showed that the only factor that roles in adolescents with low self esteem was non-democratic parenting style $(\mathrm{p}=0.001 ; \mathrm{OR}=9.939 ; 95 \% \mathrm{CI}=2.545$ to 38.813) (Table 3).

Table 2. Characteristics of subject.

\begin{tabular}{lll}
\hline Characteristics, $\mathbf{n}(\mathbf{\%})$ & Democratic parenting style $\mathbf{( N = 5 2 )}$ & Non-democratic parenting style (N=52) \\
\hline Age (years old) & $3(5.8)$ & $0(0.0)$ \\
11 & $36(69.2)$ & $35(67.3)$ \\
12 & $13(25.0)$ & $17(32.7)$ \\
Gender & & \\
Male & $26(50.0)$ & $23(44.2)$ \\
Female & $26(50.0)$ & $29(55.8)$ \\
Family income & $0(0.0)$ & $2(3.8)$ \\
\hline
\end{tabular}




\begin{tabular}{|c|c|c|}
\hline Characteristics, n (\%) & Democratic parenting style $(\mathrm{N}=52)$ & Non-democratic parenting style $(\mathrm{N}=52)$ \\
\hline$<2.173 .000$ & $28(53.8)$ & $31(59.6)$ \\
\hline $2.173 .000-5.000 .000>5.000 .000$ & $24(46.2)$ & $19(36.5)$ \\
\hline \multicolumn{3}{|l|}{ Father's education level } \\
\hline Primary school & $1(1.9)$ & $1(1.9)$ \\
\hline Junior high school & $3(5.8)$ & $1(1.9)$ \\
\hline Senior high school & $16(30.8)$ & $21(40.4)$ \\
\hline University & $32(61.5)$ & $29(55.8)$ \\
\hline \multicolumn{3}{|l|}{ Mother's education level } \\
\hline Primary school & $2(3.8)$ & $1(1.9)$ \\
\hline Junior high school & $6(11.5)$ & $3(5.8)$ \\
\hline Senior high school & $19(36.5)$ & $23(44.2)$ \\
\hline University & $25(48.1)$ & $25(48.1)$ \\
\hline \multicolumn{3}{|l|}{ Father's occupation } \\
\hline Government officer & $11(21.2)$ & $6(11.5)$ \\
\hline Private employee & $20(38.5)$ & $27(51.9)$ \\
\hline Entrepeneur & $21(40.4)$ & $19(36.5)$ \\
\hline \multicolumn{3}{|l|}{ Mother's occupation } \\
\hline Government officer & $6(11.5)$ & $5(9.6)$ \\
\hline Private employee & $17(32.7)$ & $9(17.3)$ \\
\hline Entrepeneur & $16(30.8)$ & $9(17.3)$ \\
\hline Unemployed & $13(25.0)$ & $29(55.8)$ \\
\hline \multicolumn{3}{|l|}{ Media social } \\
\hline Active user & $45(86.5)$ & $50(96.2)$ \\
\hline Non-active user & $7(13.5)$ & $2(3.8)$ \\
\hline
\end{tabular}

Table 3. Association of parenting styles with adolescent's self esteem.

\begin{tabular}{llllll}
\hline Parenting style & Low self esteem & High self esteem & PR & CI 95\% & p \\
\hline Non-democratic $\mathrm{n}(\%)$ & $17(32.7)$ & $35(67.3)$ & 5.667 & 1.766 to 18.178 & 0.001 \\
Democratic $\mathrm{n}(\%)$ & $3(5.8)$ & $49(94.2)$ & & & \\
Total & 20 & 84 & & & \\
\hline
\end{tabular}

Table 4. Multivariate logistic regression analysis of variables effecting low self-esteem in adolescents.

\begin{tabular}{llll}
\hline Variables & OR & CI 95\% & p \\
\hline Non-democratic parenting style & 9.939 & 2.545 to 38.813 & 0.001 \\
Mother's occupation (unemployed) & 0.506 & 0.168 to 1.525 & 0.226 \\
\hline
\end{tabular}

\section{Discussion}

This study was dominated by 12 years old adolescents in both groups. Age is important in shaping self-esteem, especially in adolescence, self-esteem tends to increase in young adult and decreases in old age due to a decrease of health condition, economic status and cognitive ability [18]. Self-esteem changes over time, influenced by the five domains of self-esteem, namely family, friends, school, body image, and sports activities, overall that adolescent's selfesteem dominantly influenced by friends and body image. This study showed that self-esteem wasn't different among junior high school students based on age. Self-esteem in early adolescent is more influenced by interaction with friends and satisfaction of physical appearance [21]. The difference in self-esteem is clearly seen in transition age $[18,21]$.

Female adolescents were dominant in non-democratic while in democratic parenting style was dominated by male adolescents. Gender influences self esteem, boy tends to have higher self-esteem than girl from adolescence to adulthood and correlates with father involvement because girl tend to pay attention with physical appearance, affected by hormonal changes and psychosocial effects [22-25]. In contrast to developed countries with gender equality, girl's self-esteem is not different from boy and tends to increase with age [25]. Parental income dominated 2,173,000 - 5,000,000 (above $2,150,000)$, in accordance with study in Manado which also dominated income above 2,150,000. High level of family income influences self-esteem by fulfillment of their needs, adolescent assume they were considered good in the view of others, which is the background of the emergence of selfesteem within themselves [28].

Non-permanent occupation, low family income and economic burden prone to create conflicts, adding psychological pressure on parents which will affect child fostering. Unoptimized parenting style causes low selfesteem in children. Entrepreneur fathers tend to have democratic parenting style because they have plenty free time to discuss with adolescents so that adolescents have high self-esteem. This is consistent with this study, which showed that the democratic father dominated by entrepreneurs while 
non-democratic father dominated by private employees. Researches showed occupation didn't affect maternal parenting style but was influenced by mother's willingness and ability to share time with children [26, 27]. This study was dominated by private employees in democratic mothers', while non-democratic mothers was dominated by unemployed mothers.

Parents' education level in this study was dominated by university graduate in both parenting style in accordance with the study in Denpasar-I Junior High School, which majority of parents graduate from college [28] contraly with research in Klaten which was dominated by parents graduate from high school [29]. Highly educated parents more involved in scientific activities such as seminars, workshops of child development. Newman et al showed that parents' education level correlated with adolescent's self-esteem,[30] the higher the parent's education level, the higher the adolescent self-esteem which associated with parental assistance [30]. High education level makes parents able to receive more information about appropriate childcare [29].

Active social media user tend to have lower self-esteem than non-user, due to adolescent tend to do social comparison against themselves. Social media correlates with adolescent self-esteem. Adolescent with low self-esteem interested in social comparison, which related to greater amount of time spent on Facebook, searching information about others. They tend to make social comparisons to simulate different selfimage from reality and anxious about the response of their posts in total of likes or retweets in social media [11]. In this study self-esteem and social media wasn't related which might due to different types of social media.

Numerous studies showed democratic parenting is the most ideal parenting style for self-esteem formation. Democratic parenting style trains adolescent self-esteem and becomes the foundation of their behavior and personality in the future. It is in accordance with this study which showed that less adolescent with democratic parent have low selfesteem than adolescent from non-democratic parent. Democratic parents provide discourse and insight into thinking process, doing activities and socializing well so as to encourage positive mental development, especially selfesteem [6, 8, 20, 28, 33].

Non-democratic parenting styles such as authoritarian, permissive, neglectful inversely related to adolescent's low self-esteem [30, 32, 33]. Its in accordance with this study which showed the proportion of low self-esteem is frequently in non-democratic parenting styles. Non-democratic parenting styles with imbalanced control and warmth as in authoritarian parenting style, correlates with social anxiety that will reduce adolescent self-esteem [32, 33].

The limitation of this research is that the study design was cross-sectional. This study is expected as guide for medical officers in educating parents to avoid non-democratic parenting style and as basic for further research with case control method in late adolescents with a wider coverage area so that it describes the parenting style of whole Bali.

\section{Conclusion}

Self-esteem statistically significant differ between democratic and non-democratic parenting style. Parenting style affects adolescent's self-esteem, especially nondemocratic parenting style risky for causing low self-esteem in adolescents.

\section{Funding}

The authors received no financial support for the research, authorship, and/or publication of this article.

\section{Acknowledgements}

All adolescents and their parents for participating in this study. Special thanks to Prof. Dr. dr. Raden Irawati Ismail, Sp. KJ (K), M. Epid for the Parenting Questionnaire (KPAA) and also to Prof. Dr. Saifuddin Azwar, M. A. for the Rosenberg (Indonesian version).

\section{References}

[1] Baumeister RF, Campbell JD, Krueger JI, Vohs KD. Does high self-esteem cause better performance, interpersonal success, happiness, or healthier lifestyles? Psychol Sci Public Interest. 2003; 4 (1): 1-44. doi: 10.1111/1529-1006.01431. [PubMed PMID: 26151640].

[2] Wagner J, Hoppmann C, Ram N, Gerstorf D. Self-Esteem is Relatively Stable Late in Life: The Role of Resources in the Health, Self-Regulation, and Social Domains. Dev Psychol. 2015; 51 (1): 136-49. doi: 10.1037/a0038338. [PubMed: 25546600]. [PubMed Central: PMC4397980].

[3] Masselink M, Van Roekel E, Oldehinkel AJ. Self-esteem in Early Adolescence as Predictor of Depressive Symptoms in Late Adolescence and Early Adulthood: The Mediating Role of Motivational and Social Factors. J Youth Adolesc. 2018; 47 (5): 932-946. doi: 10.1007/s10964-017-0727-z [PubMed: 28785953].[PubMed Central: PMC5878202].

[4] Hosogi M, Okada A, Fujii C, Noguchi K, Watanabe K. Importance and usefulness of evaluating self esteem in children. BioPsychoSocial Medicine. 2012; 6 (9): 1-6. doi: 10. 1186/1751-0759-6-9. [PubMed: 22433387]. [PubMed Central: PMC3337795].

[5] Robins RW, Trzesniewski KH, Tracy JL, Gosling SD, Potter J. Global self-esteem across the life span. Psychol Aging. 2002; 17 (3): 423-34. doi: 10.1037//0882-7974.17.3.423. [PubMed: $12243384]$.

[6] Aremu TA, John-Akinola YO, Desmennu AT. Relationship Between Parenting Styles and Adolescents' Self-Esteem. Int Q Community Health Educ. 2019; 39 (2): 91-9. doi: 10.1177/0272684X18811023. [PubMed: 30426845].

[7] Doi S, Fujiwara T, Isumi A, Ochi M.. Pathway of the Association Between Child Poverty and Low Self-Esteem: Results From a Population-Based Study of Adolescents in Japan. Front Psychol. 2019; 10: 937. doi: 10.3389/fpsyg.2019.00937. [PubMed: 31133920]. [PubMed Central: PMC6511812]. 
[8] Alami A, Khosravan S, Moghadam LS, Pakravan F, Hosseni F. Adolescents' Self-Esteem in Single and Two-Parent Families. Int J Community Based Nurs Midwifery. 2014; 2 (2): 69-76. [PubMed: 25349847]. [PubMed Central: PMC4201193].

[9] Kling KC, Hyde JS, Showers CJ, Buswell BN. Gender differences in self-esteem: a meta-analysis. Psychological bulletin. 1999; 125 (4): 470-500. [PubMed: 10414226].

[10] Jonassaint CR, Kochb AA, Whitfieldc KE, Hoylec RH, Richmanc LS, Siegler IC, et al. The serotonin transporter gene polymorphism (5HTTLPR) moderates the effect of adolescent environmental conditions on self-esteem in young adulthood: A structural equation modeling approach. Biological Psychology. 2012; 91 (1): 111-9. [PubMed: 22659377]. [PubMed Central: PMC3574633].

[11] Bergagna E, Tartaglia S. Self-Esteem, Social Comparison, and Facebook Use. Eur J Psychol. 2018; 14 (4): 831-845. doi: 10.5964/ejop.v14i4.1592. [PubMed: 30555588]. [PubMed Central: PMC6266525].

[12] Robson PJ. Review: Self-esteem a psychiatric view. $\mathrm{Br} J$ Psychiatry. 1988; 153: 6-15. doi: 10.1192/bjp.153.1.6. [PubMed: 3066431].

[13] Henriksen IO, Ranøyen I, Indredavik MS, Stenseng F. The role of self-esteem in the development of psychiatric problems: a three-year prospective study in a clinical sample of adolescents. Child Adolesc Psychiatry Ment Health. 2017; 11: 68. doi: 10.1186/s13034-017-0207-y. [PubMed: 29299058]. [PubMed Central: PMC5747942].

[14] Mc Gee R, Williams S. Does low self-esteem predict health compromising behavior among adolescents? Journal of adolescence. 2000; 23 (5): 569-82. doi: 10.1006/jado.2000.0344. [PubMed: 11073698].

[15] Donnellan MB, Trzesniewski KH, Robins RW, Moffitt TE, Caspi A. Low self-esteem is related to aggression, antisocial behavior and delinquency. Psychological Science. 2005; 16 (4): 328-35. doi: 10.1111/j.0956-7976.2005.01535.x. [PubMed: 15828981].

[16] Orth U, Robins RW, Roberts BW. Low self-esteem prospectively predicts depression in adolescence and young adulthood. J Pers Soc Psychol. 2008; 95 (3): 695-708. doi: 10.1037/0022-3514.95.3.695. [PubMed: 18729703].

[17] Zahedani ZZ, Rezaee R, Yazdani Z, Bagheri S, Nabeiei P. The influence of parenting style on academic achievement and career path. J Adv Med Educ Prof. 2016; 4 (3): 130-4. [PubMed: 27382580]. [PubMed Central: PMC4927255].

[18] Orth U, Robins RW, Widaman KF. Life span development of self esteem and its effects on important life outcomes. J Pers Soc Psychol. 2012; 102 (6): 1271-88. doi: 10.1037/a0025558. [PubMed: 21942279].

[19] Power TG. Parenting Dimensions and Styles: A Brief History and Recommendations for Future Research. Child Obes. 2013; 9 (1): S14-S21. doi: 10.1089/chi.2013.0034. [PubMed: 23944920]. [PubMed Central: PMC3746212].

[20] Kuppens S, Ceulemans E. Parenting Styles: A Closer Look at a Well-Known Concept. J Child Fam Stud. 2019; 28 (1): 16881. doi: 10.1007/s10826-018-1242-x. [PubMed: 30679898]. [PubMed Central: PMC6323136].
[21] van den Berg PA, Mond J, Eisenberg M, Ackard D, NeumarkSztainer D. The link between body dissatisfaction and selfesteem in adolescents: Similarities across gender, age, weight status, race/ethnicity, and socioeconomic status. J Adolesc Health. 2010 Sep; 47 (3): 290-6. [PubMed: 20708569]. [PubMed Central: PMC2923488].

[22] Orth U. The family environment in early childhood has a long-term effect on self-esteem: A longitudinal study from birth to age 27 years. J Pers Soc Psychol. 2018; 114 (4): 63755. doi: 10.1037/pspp0000143. [PubMed: 28182449].

[23] Trzesniewski KH, Donnellan MB, Robins RW. Stability of self-esteem across the life span. J Pers Soc Psychol. 2003; 84 (1): 205-20. [PubMed: 12518980].

[24] Quatman T, Watson CM. Gender Differences in Adolescent Self-Esteem: An Exploration of Domains. J Genet Psychol. doi: 10.1080/00221320109597883. 2001; 162 (1): 93-117. [PubMed: 11338443].

[25] Bleidorn W, Arslan RC, Denissen JJA, Rentfrow PJ, Gebauer JE, Potter J, et al. Age and Gender Differences in SelfEsteem-A Cross-Cultural Window. J Pers Soc Psychol. 2016; 111 (3): 396-410. doi: 10.1037/pspp0000078. [PubMed: 26692356].

[26] Whitbeck LB, Simons RL, Conger RD, Wickrama KAS, Ackley KA, Junior GHE. The effects of Parent's working conditions and family economic hardship on parenting behavior and children self-efficacy. Social Psychology Quarterly. 1997; 60 (4): 291-303.

[27] Poduval J, Poduval M. Working Mothers: How Much Working, How Much Mothers, And Where Is The Womanhood? Mens Sana Monogr. 2009; 7 (1): 63-79. doi: 10.4103/0973-1229.41799. [PubMed: 21836780]. [PubMed Central: PMC3151456].

[28] Pratiwi KI, Rustika IM. Peran pola asuh autoritatif dan konsep diri terhadap kecerdasan sosial remaja awal Sekolah Menengah Pertama Negeri di Denpasar. Jurnal Psikologi Udayana 2017; 4 (2): 448-59.

[29] Zamroh A. Hubungan antara tingkat pendidikan dan pola asuh orangtua dengan prestasi belajar IPS pada siswa SMP sekecamatan Klaten Selatan. Social studies. 2017; 6 (6): 720-8.

[30] Newman J, Hamide G, Guan S, Lee JE, Li X, Sasaki Y. Relationship between maternal parenting style and high school achievement and self esteem in China, Turkey and USA. Journal of Comparative Family. 2017; 46 (2): 265-89.

[31] Martinez I, Garcia JF. Parenting styles and adolescents' self esteem in Brazil. Psychological Report. 2007; 100: 731-45. doi: 10.2466/pr0.100.3.731-745. [PubMed: 17688087].

[32] Yousaf S. The Relation between Self-Esteem, Parenting Style and Social Anxiety in Girls. Journal of Education and Practice. 2015; 6 (1): 140-2.

[33] Gómez-Ortiz O, Romera EM, Jiménez-Castillejo R, OrtegaRuiz R, García-López LJ. Parenting practices and adolescent social anxiety: A direct or indirect relationship? Int J Clin Health Psychol. 2019; 19 (2): 124-133. doi: 10.1016/j.ijchp.2019.04.001. [PubMed: 31193117]. [PubMed Central: PMC6517642]. 